Available online at https://jurnal.stmikroyal.ac.id/index.php/jurdimas

\title{
PELATIHAN PENULISAN DAN PUBLIKASI ARTIKEL ILMIAH HASIL PENELITIAN TINDAKAN KELAS BAGI GURU DI KOTA MAGELANG
}

\author{
Athia Fidian', Agrissto Bintang Aji Pradana ${ }^{2}$ \\ ${ }^{1}$ Fakultas Ilmu Kesehatan, Universitas Muhammadiyah Magelang \\ ${ }^{2}$ Fakultas Keguruan dan Ilmu Pendidikan, Universitas Muhammadiyah Magelang \\ email:*athiafidian@ummgl.ac.id
}

\begin{abstract}
Based on data from Dinas Pendidikan dan Kebudayaan Kota Magelang in July 2018, the highest number of teachers is in group of IV / a. One of the influencing factors is their reluctance to make scientific publications for the promotion. They do not have enough information about the journal to be addressed, do not yet understand what must be stated in a scientific article, systematics of writing, and how to make a bibliography. The online process is also one of the things they find difficult. The purpose of community service is to improve the ability of teachers to write scientific articles. Partners in this activity were 12 elementary and junior high school teachers in Dinas Pendidikan dan Kebudayaan Kota Magelang. The implementation time is 4 months consisting of 3 training sessions and following assistance. The material presented during the training included (1) scientific articles in the ranks of teachers, (2) reference managers, and (3) article submissions. The results of the training showed that all participants increasingly understood how to use scientific articles for promotion. In addition, 58\% of participants are more aware and able to use the reference manager in Ms Office Word. In the third material, $67 \%$ of participants understood and were able to register and submit articles in the Paedagogie Journal.
\end{abstract}

Keywords: scientific articles, training, scientific publications, classroom action research

\begin{abstract}
Abstrak: Berdasarkan data dari Dinas Pendidikan dan Kebudayaan Kota Magelang pada bulan Juli 2018, jumlah terbanyak guru berada pada golongan IV/a. Salah satu faktor yang mempengaruhi adalah keengganan mereka dalam membuat publikasi ilmiah untuk kenaikan pangkat. Mereka tidak memiliki informasi yang cukup mengenai jurnal yang akan dituju, belum memahami apa yang harus dituangkan dalam sebuah artikel ilmiah, sistematika penulisan, serta cara membuat daftar pustaka. Proses online juga menjadi salah satu hal yang mereka anggap sulit. Tujuan dari pengabdian masyarakat ini adalah meningkatkan kemampuan guru dalam menulis artikel ilmiah. Mitra dalam kegiatan ini adalah 12 orang guru SD dan SMP di lingkungan Dinas Pendidikan dan Kebudayan di Kota Magelang. Waktu pelaksanaan yakni 4 bulan terdiri dari 3 kali pelatihan dan ikuti pendampingan. Materi yang disampaikan pada saat pelatihan antara lain (1) artikel ilmiah dalam kepangkatan guru, (2) reference manager, dan (3) article submission. Hasil pelatihan menunjukkan bahwa seluruh peserta semakin memahami bagaimana memanfaatkan artikel ilmiah bagi pengajuan kenaikan pangkat. Selain itu, 58\% peserta semakin paham dan mampu cara menggunakan reference manager pada Ms Office Word. Pada materi ke-3, sebanyak $67 \%$ peserta memahami dan mampu untuk registrasi dan submit artikel pada Jurnal Paedagogie.
\end{abstract}

Kata kunci: artikel ilmiah, pelatihan, publikasi ilmiah, penelitian tindakan kelas 
Available online at https://jurnal.stmikroyal.ac.id/index.php/jurdimas

\section{PENDAHULUAN}

Guru profesional diwajibkan untuk senantiasa melakukan kegiatan pengembangan keprofesian berkelanjutan untuk meningkatkan kemampuan diri guru dalam melaksanakan tugasnya. Kegiatan pengembangan keprofesian berkelanjutan bagi guru meliputi kegiatan pengembangan diri, publikasi ilmiah dan karya inovatif yang merupakan unsur utama dalam pengembangan karir guru (Kemdikbud, 2016).

Berdasarkan data dari Dinas

Pendidikan dan Kebudayaan Kota Magelang per bulan Juli 2018, jumlah terbanyak guru berada pada golongan IV/a. Sebagai perbandingan, 420 guru PNS dari berbagai bidang ilmu 2 orang memiliki golongan di bawah III/a, 5 orang golongan III/a, 34 orang golongan III/b, 53 orang golongan III/c, 43 orang golongan III/d, 272 orang golongan IV/a, dan 11 orang memiliki golongan di atas IV/a. Salah satu faktornya adalah keengganan mereka dalam membuat publikasi ilmiah untuk kenaikan pangkat (Dinas Pendidikan dan Kebudayaan Kota Magelang Tahun 2018).

Dinas Pendidikan dan

Kebudayaan sudah berupaya mendorong peningkatan kuantitas kualitas guru peneliti dan penulis. Salah satunya ialah pengalokasian dana penulisan artikel ilmiah hasil PTK desiminasi hasil penelitian yang diselenggarakan secara periodik berkoordinasi dengan Musyawarah Guru Mata Pelajaran (MGMP).

Meskipun demikian, upaya ini kurang mendapat sambutan positif dari para guru. Iklim akademis yang dibangun di Kota Magelang baru mampu mendukung aspek pembelajaran, dan belum mampu mendorong guru untuk lebih berkarya dalam bentuk penelitian dan tulisan ilmiah. Bahkan pihak Dinas sendiri seringkali mengalami kendala dalam penerbitan jurnal pada tiap edisinya dikarenakan minimnya jumlah artikel hasil PTK yang dikirim ke dewan redaksi jurnal. Sedangkan jumlah minimal yang dipersyaratkan untuk diterbitkan ialah 10 artikel. Selain itu, dari beberapa artikel yang masuk pada tim editorial Jurnal Paedagogie Universitas Muhammadiyah Magelang, terlihat masih banyak guru yang belum paham mengenai tata tulis artikel jurnal, maupun mengikuti proses review.

\section{METODE}

$\begin{array}{cll}\text { Pengabdian } & \text { masyarakat ini } \\ \text { dilaksanakan dalam } & \text { waktu } 4 \text { bulan. }\end{array}$ Kegiatan ini diikuti oleh 12 peserta, yakni guru SD dan SMP di lingkungan Dinas Pendidikan dan Kebudayaan Kota Magelang. Metode kegiatan yang dilaksanakan guna menyelesaikan permasalahan mitra adalah dengan pelatihan dan pendampingan yang dibagi menjadi 3 pertemuan tatap muka. Materi yang disampaikan dalam pertemuan pertama adalah konsep dasar artikel ilmiah dan konten penulisan artikel ilmiah seperti menentukan judul artikel, cara menyajikan masalah pada bagian pendahuluan, cara memaparkan hasil penelitian, cara menulis pembahasan, cara mencari sumber rujukan untuk memperkuat tulisan pada bagian pembahasan, cara menulis simpulan. Selain itu, peserta diberi pemahaman mengenai pemanfaatan artikel ilmiah untuk kenaikan pangkat guru. Pertemuan ke-2 lebih ditekankan pada pemahaman plagiarisme dan pelatihan reference manager. Pada pertemuan ke-3, peserta memperoleh pelatihan mengenai jurnal nasional, mulai dari registrasi, hingga 
Available online at https://jurnal.stmikroyal.ac.id/index.php/jurdimas

Tabel 1. Metode Pelaksanaan Pengabdian

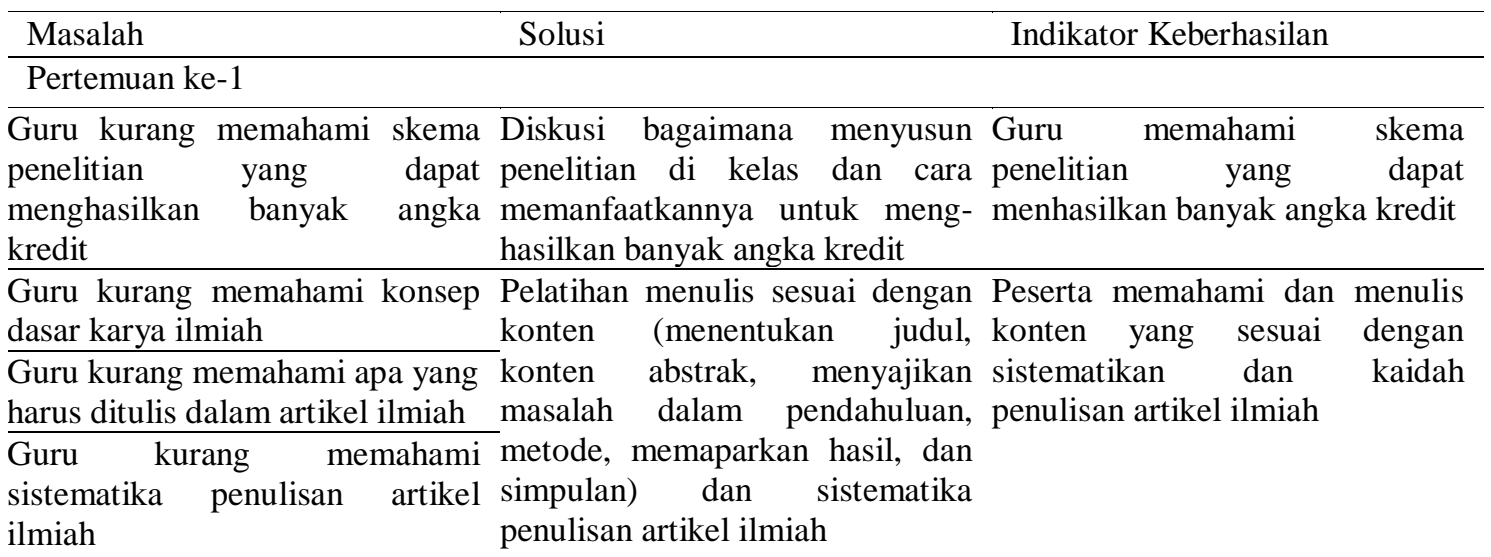

\begin{tabular}{|c|c|}
\hline \multicolumn{2}{|l|}{ Pertemuan ke-2 } \\
\hline $\begin{array}{l}\text { Guru tidak dapat membuat daftar } \\
\text { pustaka otomatis }\end{array}$ & $\begin{array}{l}\text { Pelatihan dan pendampingan Peserta dapat membuat daftar } \\
\text { membuat daftar pustaka otomatis pustaka otomatis dengan benar } \\
\text { dengan reference manager }\end{array}$ \\
\hline \multicolumn{2}{|l|}{ Pertemuan ke-3 } \\
\hline $\begin{array}{l}\text { Guru tidak memiliki referensi } \\
\text { jurnal publikasi artikel hasil PTK }\end{array}$ & $\begin{array}{l}\text { Seluruh peserta mengenal jurnal } \\
\text { Paedagogie UMMagelang }\end{array}$ \\
\hline $\begin{array}{l}\text { Guru kurang memahami proses } \\
\text { publikasi online pada jurnal } \\
\text { penetilian }\end{array}$ & 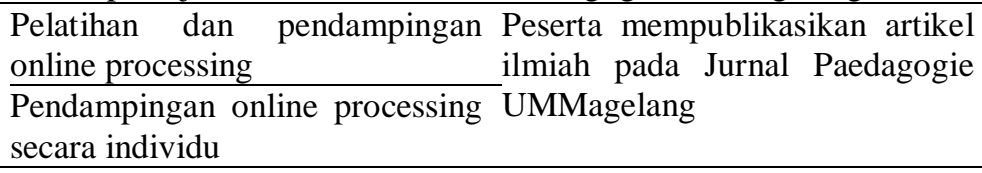 \\
\hline
\end{tabular}

unggah artikel. Setelah itu, mitra mendapat pendampingan secara mandiri terkait penulisan artikel dan pengunggahannya pada Jurnal Nasional Paedagogie. Berikut adalah tabel skema kegiatan pengabdian ini.

\section{PEMBAHASAN}

Pelatihan penulisan artikel ilmiah dilaksanakan melalui tiga kali pertemuan tatap muka dan dilanjutkan dengan pendampingan. Terdapat beberapa kendala dalam persiapannya seperti perijinan pelaksanaan kegiatan, publikasi kegiatan kepada guru, serta penentuan waktu pelaksanaan. Namun demikian, 12 guru dari tingkat SD dan SMP berminat untuk mengikuti kegiatan pelatihan.

Pertemuan pertama dilaksanakan pada tanggal 29 Maret 2019 di aula SDN
Cacaban 6 Kota Magelang. Pelatihan ini dilaksanakan melalui penyuluhan terkait penulisan artikel dan manfaatnya dalm kenaikan pangkat guru. Materi yang disampaikan adalah terkait sistematika dan konten artikel ilmiah. Peserta berdiskusi mengenai apa saja yang dapat disebut sebgaai artikel ilmiah, konten apa saja yang dapat ditulis dalam artikel ilmiah, serta struktur artikel ilmiah mulai dari judul hingga daftar pustaka serta lampirannya. Hal ini perlu diberikan karena seringkali artikel ilmiah guru berisi tulisan yang hanya dipindah dari laporan Penelitian Tindakan Kelas.

Pertemuan ke-2 dilaksanakan pada tanggal 6 April 2019 di Gedung FIKES Universitas Muhammadiyah Magelang. Tim pelaksana menyampaikan materi mengenai word formatting dan reference manager. Materi ini sangat perlu untuk disampaikan karena salah 
Available online at https://jurnal.stmikroyal.ac.id/index.php/jurdimas

satu factor yang membuat peserta enggan untuk menulis artikel ilmiah adalah banyaknya waktu yang tersita pada saat menulis. Dengan keterampilan dalam pemanfaatan word formatting, peserta lebih paham dan mempercepat penulisan artikel. Seringkali penulis hanya mencontoh PTK dari penulis lain pada tahuntahun sebelumnya. Dengan pengetahuan akan plagiarism, peserta lebih cermat dalam mengutip pernyataan atau ide dari berbagai sumber. Peserta juga dilatih untuk memanfaatkan Ms Office Word mereka untuk membuat kutipan dan daftar pustaka otomatis. Dengan demikian, mereka tidak perlu menyusun daftar pustaka satu per satu karena sudah terekap secara otomatis.

Pada pertemuan ke-3, tim pelaksana menyampaikan materi mengenai jurnal Paedagogie dan cara mengunggah artikel. Jurnal ini menjadi alternatif tujuan publikasi artikel peserta untuk kenaikan pangkat. Dengan mempublikasi artikel pada Jurnal Paedagogie, peserta memperoleh poin 2 untuk angka kredit yang diajukan (Kemendikbud, 2019a, 2019b). Peserta juga dilatih untuk membuat akun pada jurnal nasional serta mengunggah artikel. Hal ini sangat bermanfaat bagi peserta karena mereka sangat awam dengan online processing.

\section{SIMPULAN}

Pelaksanaan kegiatan pengabdian kepada masyarakat yang berjudul" PKU bagi Guru SD di Kota Magelang dalam Penulisan dan Publikasi Artikel Ilmiah Hasil Penelitian Tindakan Kelas" telah terlaksana dengan baik dan sesuai dengan rencana. Tujuan dari kegiatan ini dapat tercapai dilihat dari meningkatnya pemahaman terkait penulisan artikel baik konten maupun sistematikanya. Selain itu, terdapat pula peningkatan pemahaman terhadap pemanfaatan artikel ilmiah bagi penilaian angka kredit guru mulai dari peraturan maupun teknis penilaiannya. Setelah pelatihan ini peningkatan keterampilan juga terlihat terkait penggunaan reference manager serta online processing. Dengan demikian secara keseluruhan kegiatan ini dikatakan berhasil.

\section{UCAPAN TERIMA KASIH}

Penulis mengucapkan terima kasih kepada Lembaga Penelitian, Pengembangan dan Pengabdian Masyarakat, Universitas Muhammadiyah Magelang yang telah membiayai penelitian ini melalui Skema Pendanaan Program Kemitraan Universitas (PKU) Tahun 2018/2019.

\section{DAFTAR PUSTAKA}

Kemdikbud. 2016. Penilaian Kegiatan Pengembangan Keprofesian Berkelanjutan Guna Mendukung Pengembangan Profesi Guru Pembelajar. Jakarta: Kemndikbud.

Kemendikbud. 2019a. Buku 4 Pedoman Kegiatan Pengembangan Keprofesian Berkelanjutan dan Angka Kreditnya.

Kemendikbud. 2019b. Buku 5 Pedoman

Penilaian

Kegiatan

Pengembangan Keprofesian 